These materials provide information not only on the missionary work with which they are primarily concerned but also on life and activities and historical and political developments in Africa, and offer insight into African cultures by those intimately involved with them. Also documented are the processes and sometimes accompanying struggles involved in transferring responsibility from a foreign mission to a national church. Types of materials include minutes, reports, correspondence, oral history interviews, photographs, films, video tapes, slides, maps and posters. Facilities are located at the Billy Graham Center on the campus of Wheaton College. The Reading Room is open to the public from $8.30 \mathrm{am}-4.30 \mathrm{pm}$ on weekdays and $8.00 \mathrm{am}-12.00$ noon on Saturdays. Photocopying is also available. For further information, or to be placed on the mailing list to receive free semiannual checklists of newly processed collections, please direct inquiries to: BGC Archives, Wheaton College, Wheaton, IL 60187 (USA), or call 312-260-5910.

\title{
CENTRO DE ESTUDOS DOS POVOS E CULTURAS DE EXPRESSĀO PORTUGUESA (CEPCEP)
}

Following the successful series of seminars on 'Religion in Africa', given in Lisbon and Braga over the winter and spring of 1983-84, an agreement was concluded on 15 April 1984 between the International African Institute, represented by Professor J. F. Ade Ajayi, and CEPCEP, represented by Professor José de Freitas Ferreira, to co-operate along the following lines: (1) Planning, programming and joint implementation of seminars and courses on Africa subjects, such as the seminars on education in Africa to be offered during the academic year of 1984-85. (2) Joint development of research projects of mutual interest on African peoples and cultures. (3) Sponsoring joint publications on African subjects. (4) Development of other concrete activities which will provide a further basis for future collaboration, such as the West African Museum project based in Ivory Coast and including within its scope Guinea Bissau. (5) Opening of an IAI office in CEPCEP to further diffuse and encourage IAI activities in the Portuguese speaking countries.

\section{CONFERENCE ON ADVANCING AGRICULTURAL PRODUCTION IN AFRICA}

An international conference on 'Advancing Agricultural Production in Africa', was held at Arusha, 12-18 February 1984. Jointly sponsored by the Commonwealth Agricultural Bureau and the Government of Tanzania, it was attended by nearly four hundred delegates from thirty-six countries. Over eighty papers were presented, grouped under three themes of 'Crop production, protection and utilization', 'Annual productivity and health - integration with marketing and consumer preference' and 'National resources management'. The introductory address was given by Mwalimu Dr Julius $\mathrm{K}$. Nyerere, President of Tanzania; the keynote address by Dr D. Belshaw of the University of East Anglia in the unforeseen absence of the Special Adviser to the President of Nigeria; and the concluding review by Professor A. H. Bunting, lately of the University of Reading. The proceedings of the conference are to be published and further information may be had from P. Rimington, CAB, Farnham House, Farnham Royal, Slough SL2 3BN, UK (Tel: 02814-2662). 